\title{
Redox Proteomics in Some Age-Related Neurodegenerative Disorders or Models Thereof
}

\author{
D. Allan Butterfield, ${ }^{* \dagger}$ Hafiz Mohmmad Abdul, ${ }^{* \dagger}$ Shelley Newman, ${ }^{* \dagger}$ and Tanea Reed ${ }^{* \dagger}$ \\ *Department of Chemistry, Center of Membrane Sciences, University of Kentucky, Lexington, Kentucky; and ${ }^{\dagger}$ Sanders-Brown \\ Center on Aging, University of Kentucky, Lexington, Kentucky
}

\begin{abstract}
Summary: Neurodegenerative diseases cause memory loss and cognitive impairment. Results from basic and clinical scientific research suggest a complex network of mechanisms involved in the process of neurodegeneration. Progress in treatment of such disorders requires researchers to better understand the functions of proteins involved in neurodegenerative diseases, to characterize their role in pathogenic disease mechanisms, and to explore their roles in the diagnosis, treatment, and prevention of neurodegenerative diseases. A variety of conditions of neurodegenerative diseases often lead to post-translational modifications of proteins, including oxidation and nitration, which might be involved in the pathogenesis of neurodegenerative diseases. Redox proteomics, a subset of proteomics, has made possible the identification of specifically oxidized proteins in
\end{abstract}

neurodegenerative disorders, providing insight into a multitude of pathways that govern behavior and cognition and the response of the nervous system to injury and disease. Proteomic analyses are particularly suitable to elucidate post-translational modifications, expression levels, and protein-protein interactions of thousands of proteins at a time. Complementing the valuable information generated through the integrative knowledge of protein expression and function should enable the development of more efficient diagnostic tools and therapeutic modalities. Here we review redox proteomic studies of some neurodegenerative diseases. Key Words: Redox proteomics, $\mathrm{A} \beta$, (1-42), amyloid beta-peptide, AD, Alzheimer's disease, mass spectrometry, protein oxidation.

\section{INTRODUCTION}

Age-related neurodegenerative diseases are conditions that affect brain function as a result of deterioration of neurons as a function of the patient's age. Currently there are millions of people suffering from neurodegenerative diseases and it is believed that this number will increase due to aging of developed societies. Among the neurodegenerative diseases, Alzheimer's disease (AD) is the most common cause of dementia. AD is characterized clinically by progressive intellectual deterioration together with declining activities of daily living and neuropsychiatric symptoms or behavioral changes. Pathologically, neuronal and synapse loss, together with deposition of amyloid plaques ${ }^{1}$ and neurofibrillary tangles, are observed. Genetic factors are known to be important and polymorphisms in three different autosomal dominant genes, presenilin 1 , presenilin $2,{ }^{2}$ and amyloid

Address correspondence and reprint requests to: Prof. D. Allan Butterfield, Department of Chemistry, Center of Membrane Sciences, and Sanders-Brown Center on Aging, University of Kentucky, Lexington KY 40506. E-mail:dabcns@uky.edu. precursor protein, have been identified that account for a small number of cases of familial, early-onset AD. For late onset $\mathrm{AD}$ (LOAD), one susceptibility gene has so far been definitely identified, the epsilon 4 allele of the APOE gene. ${ }^{3}$

Next to AD, Parkinson's disease (PD) is the second most prevalent neurodegenerative disorder. ${ }^{4}$ Pathological alterations of the substantia nigra, an area within the basal ganglia of the brain, is observed. ${ }^{5}$ The disease involves progressive alterations of the extrapyramidal system, which controls and adjusts communication between neurons in the brain and muscles in the human body. Huntington disease (HD) and amyotrophic lateral sclerosis (ALS) are two other age-related neurodegenerative diseases. HD is inherited in an autosomal dominant manner and is characterized by abnormal body movements called chorea and loss of memory. ALS, sometimes called Lou Gehrig's disease, is a progressive, invariably fatal motor neuron disease. There is increasing evidence of an overlap of these age-related neurodegenerative disorders with a contribution of environmental, epigenetic, and genetic factors. ${ }^{6}$ 
Accumulating evidence suggests a role for oxidative stress in the pathophysiology of AD. Protein oxidation, lipid peroxidation, free radical formation, 3-nitrotyrosine (3-NT), advanced glycation end products, and DNA oxidation, among other markers of oxidative stress, are reported for $\mathrm{AD} .^{7-10}$ Amyloid $\beta$-peptide $(\mathrm{A} \beta)$, formed from proteolytic processing of amyloid precursor protein (APP), is deposited in AD brain. Recent studies implicate oligomeric forms of $A \beta$ as the causative agent of this disorder. ${ }^{11,12} \mathrm{~A} \beta$ causes oxidative stress in vitro ${ }^{13-15}$ and in vivo. ${ }^{16-21} \mathrm{~A} \beta$-induced lipid peroxidation leads to increased formation of 4-hydroxy-2-nonenal (HNE) in neurons and is also observed in AD brain and CSF. ${ }^{21,22}$ Further, vitamin $\mathrm{E}$ ameliorates $\mathrm{A} \beta(1-42)$-induced toxicity, supporting a role of oxidative damage in AD pathology. ${ }^{17}$ More recently, the pathogenesis of several other neurodegenerative diseases has also been linked to oxidative stress. ${ }^{23,24}$ In this review we focus our attention on the effects of oxidative stress in some age-related neurodegenerative diseases and aging brain, with emphasis on human and rodent brain studies relevant to $\mathrm{AD}$, mild cognitive impairment (MCI), PD, ALS, and HD.

Immunoprecipitation is a procedure by which peptides or proteins that react specifically with an antibody are removed from solution. Physical characteristics such as molecular weight and isoelectric point or quantity of protein are determined by this procedure. Immunoprecipitation cannot be used as a universal technique to identify proteins due to the time-consuming and laborious nature of this process. Apart from the other potential concerns, among which are the a priori lack of knowledge of the protein identity and post-translational modifications. Moreover, the potential limitation that the antibody to the protein of interest is unavailable limits detection of proteins by Western blot analysis. Redox proteomics, which couples the 2D-gel electrophoresis separation of proteins with high-resolution mass spectrometric techniques and powerful bioinformatic analysis, is a unique approach to identify oxidatively modified brain proteins. ${ }^{25}$ Earlier studies demonstrate the use of 2D-gel electrophoresis for generating molecular barcodes, which may be useful for the clinical differentiation of AD patients from normal subjects. ${ }^{26}$ Moreover, the redox proteomics approach deals with the complex of proteins expressed in a biological system (both in normal as well as diseased conditions), their structures, interactions, and post-translational modifications and have been developed to allow for thousands of proteins to be identified and quantified in a single experiment.

\section{PRINCIPLES OF REDOX}

\section{Two-dimensional gel electrophoresis}

The relative amounts of proteins expressed by a particular organism, tissue, or cell in a perturbed system (e.g., a disease state or after drug treatment) is compared with the unperturbed state, and the separation of these complex protein mixtures into single detectable protein spots is commonly performed using two-dimensional polyacrylamide electrophoresis (2D-PAGE) ${ }^{27}$ The first dimension of 2D-PAGE is isoelectric focusing, in which proteins are separated in an immobilized $\mathrm{pH}$ gradient (IPG) until attaining the $\mathrm{pH}$ of the stationary phase where their net charge is zero, termed the isoelectric point (pI) of the protein. In the second dimension, proteins are further separated by electrophoresis in the presence of SDS (SDS-PAGE) based on the relative molecular mobility (related to molecular mass). ${ }^{26}$

The main information obtained from a 2D-PAGE map is protein profiling, which allows comparison between different samples to identify differences in protein expression $^{26,28}$ and post-translational modifications that involve changes in the total charge of the protein. The limitations of this method include the difficulties for solubilization and resolution of bilayer-resident proteins, the limited $\mathrm{pH}$ range (usually $3-10$ ) that the strips provide, which precludes the detection of proteins that fall within the very basic range, low-abundant proteins that remain absent on the 2D-PAGE map and are thus silent for proteomics analysis, representing a fundamental challenge when proteomics is applied to samples. Commercially available IPG strips of the basic $\mathrm{pH}$ range and narrow range $\mathrm{pH}$ strips (as low as $1 \mathrm{pH}$ unit) have partially overcome these limitations recently.

Another quantitative technique is the use of HPLC to achieve separation of peptides produced by trypsin digestion of a given protein mixture, referred to as $2 \mathrm{D}$ HPLC, which utilizes chromatographic separation of the peptides followed by mass spectrometry (MS) analysis. By isotope-labeling specific amino acid side chains, the differences in expression of a protein can be compared and evaluated between two samples by a technique referred to as isotopically coded affinity tags (ICAT). ${ }^{29,30}$ This technique was used to quantify relative changes in the proteome of human CSF obtained from the lumbar cistern. ${ }^{30}$ In our proteomics approach to identify specifically oxidized proteins, we applied 2D-gel electrophoresis, paralleled with immunochemical detection of protein carbonyls, followed by MS analysis, as shown in Figure 1.

The identification of carbonylated proteins in the experimental or disease and control samples is determined by $2 \mathrm{D}$ Oxyblot analysis, in which the proteins are transferred onto the PVDF membrane from the gel followed by probing the carbonyl reactivity with specific antibody. The anti-DNP immunoreactivity of individual proteins is normalized to their content by matching 2D Oxyblots with their respective 2D gel images. This procedure allows comparison of oxidation levels of proteins ${ }^{25}$ in 


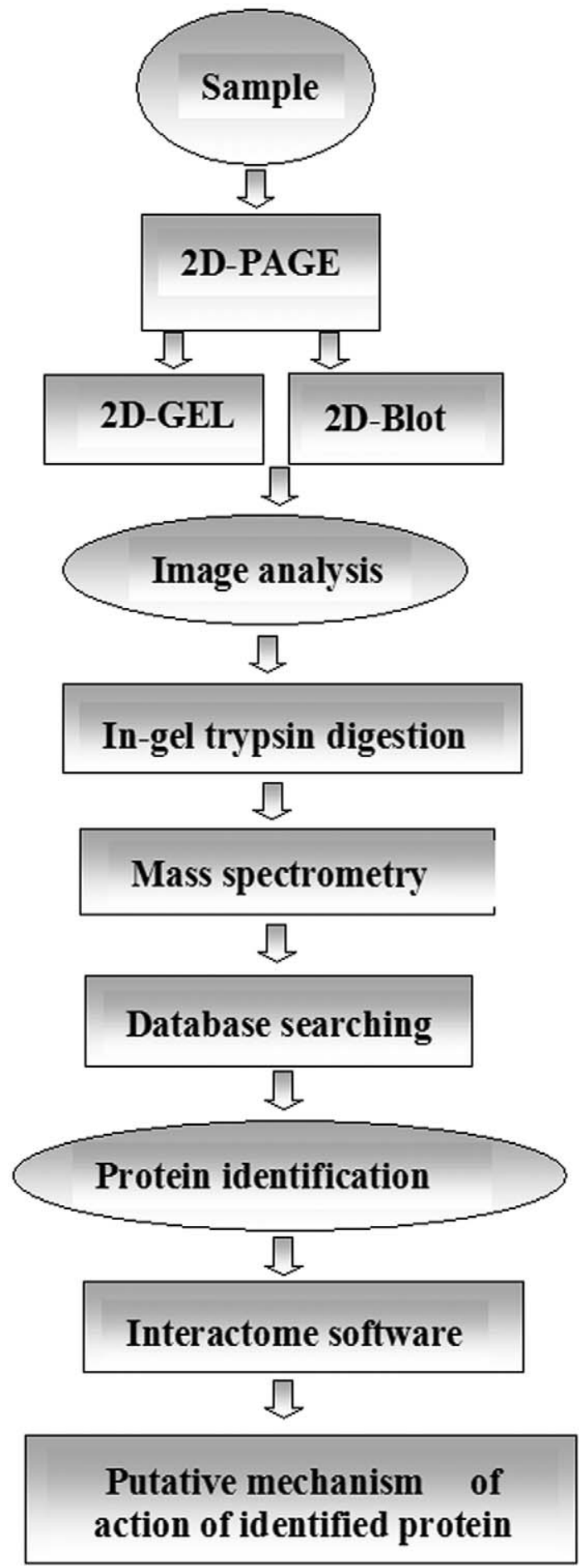

FIG. 1. Schematic representation of identification of oxidatively modified proteins by redox proteomics. In neurodegenerative diseases, redox-proteomics analysis is conducted to identify specifically oxidized proteins by coupling 2D-gel electrophoresis with immunochemical detection of protein carbonyls (by antiDNP immunoreactivity) followed by mass spectrometry analysis.

experimental (disease condition) versus control groups using statistical analysis (FIG. 1).

Though other methods involving chromatography are under development, 2D-PAGE is currently a widely employed method capable of separating complex mixtures of thousands of proteins as found in biological samples. The continuous modification and improvement of the technique has made 2D-PAGE a reasonably reliable method; but as noted above, this approach still presents many challenges to overcome.

\section{Mass spectrometry and database searching}

Once specific proteins have been selected, they are excised from the gel and fragmented into peptide components by "in-gel digestion" with a specific protease (usually trypsin). The resulting peptide mixture can then be analyzed by implementing a two-stage sequential approach using two types of MS: matrix assisted laser desorption/ionization-mass spectrometry (MALDI-MS) and electrospray ionization-mass spectrometry (ESIMS). The peptides resulting from the trypsin-mediated sequence-specific proteolysis constitute mass fingerprints that are characteristic of a particular protein and aid in identifying the protein. This process is called peptide mass mapping, which involves the use of MS coupled with a database (FIG. 1) containing protein sequences to which the experimental masses are compared. The potential of MS to yield comprehensive profiles of peptides and proteins in biological samples without the need to carry out protein separation has attracted recent interest.

An additional proteomics tool in which mass spectrometry is used is surface-enhanced laser desportion/ ionization time-of-flight (SELDI-TOF). SELDI-TOF is an approach that couples the methods of chromatographic sample preparation with MS analysis. The SELDI technique is based on a chip with a surface that has been either chemically or biochemically modified to optimize isolation of a particular group of proteins. Such biochemical modifications take advantage of antibodyantigen, receptor-ligand, and DNA-protein interactions, while chemical modifications include creating hydrophobic, hydrophilic, anionic, cationic, or metallic surfaces. ${ }^{31}$ This system can be used to screen biomarkers from a variety of complex samples, including blood, urine, serum, and plasma, can detect post-translational modifications such as glycosylation and phosphorylation, and, moreover, requires a small sample volume. However, the limitations of this technique include proteins with low molecular mass and difficulty to specifically identify a protein that is differentially expressed. ${ }^{32}$

The information obtained by MS analysis is further analyzed for protein identification by on-line protein databases, such as SwissProt. ${ }^{33}$ This system uses identification tools based on computer algorithms that are freely accessible through the internet. For each entry, the search engine produces a probability score, which is calculated by a mathematical algorithm that is specific for each 
search engine. Any hit with a score higher than the one obtained from the search (e.g., $p<0.05$ ) has a legitimate chance to be the protein cut from a given spot. In addition, the molecular weight and the $\mathrm{pI}$ of the protein are calculated based on the position in the 2D map to avoid any false-positive identification. Immunochemical methods are also performed to support the findings and further validate protein identification. ${ }^{34}$

\section{REDOX PROTEOMICS STUDIES IN NEURODEGENERATIVE DISORDERS}

\section{Alzheimer's disease}

Oxidative stress is extensive in $\mathrm{AD}$ brain. ${ }^{13,35,36}$ Protein oxidation, lipid peroxidation, free radical formation, 3-NT (formed by the action of peroxynitrite and subsequent reactions), advanced glycation end products, DNA oxidation, among other markers of oxidative stress, are reported for $\mathrm{AD} .^{7-10,22,36-38}$ Amyloid $\beta$-peptide, particularly the 42 -amino acid residue form $[\mathrm{A} \beta(1-42)]$, plays a central role in the pathogenesis of AD. ${ }^{1}$ Mutations in presenilin-1, presenilin-2, and APP genes lead to excessive amounts of $\mathrm{A} \beta(1-42)$ in the brain and are the major cause for inherited AD. Our laboratory postulated an $A \beta(1-42)$ induced model for neurodegeneration in $\mathrm{AD}$ brain based on the oxidative stress associated with $\mathrm{A} \beta(1-$ 42). ${ }^{36,39}$ Consistent with the model, it is proposed that $\mathrm{A} \beta(1-42)$ induces and antioxidants inhibit a variety of changes, including protein oxidation, ${ }^{17}$ lipid peroxidation, ${ }^{21,36}$ and reactive oxygen species production ${ }^{40}$ as well as other markers of oxidative stress. ${ }^{36}$

\section{Redox proteomic studies on oxidatively modified proteins in human $A D$ brain}

In $\mathrm{AD}$ brain, protein oxidation is increased as indexed by protein carbonyls ${ }^{41}$ and 3-NT levels. ${ }^{10,37}$ However, the knowledge of specifically oxidized proteins is limited. It is necessary to identify specifically oxidized proteins, which would enable us to establish a link between oxidative stress and neurodegeneration in AD. There are many potential applications of proteomics in neuroscience: comparative protein expression profiling, mapping of protein-protein interaction, post-translational protein modification profiling, determination of the neuroproteome, and neurometabolomics (expression studies that provide a novel foundation for re-evaluating the contributions of specific genes to the metabolic complexity and emphasize their impact on multiple biochemical pathways), ${ }^{42}$ neuropharmacoproteomics (targeted pathway-related proteomic studies of therapeutic potential) in brain, and many others. Our laboratory has used a redox proteomics approach to study post-translational modifications of proteins in AD brains, in particular, oxidative modifications.
The first use of proteomics to identify specifically oxidized proteins in $\mathrm{AD}$ brain led to the identification of several specifically oxidized proteins: creatine kinase BB (CK), glutamine synthase (GS), ubiquitin carboxy-terminal hydrolase/L (UCH/l), $\alpha$-enolase, and dihydropyrimidinase related protein 2 (DRP2). ${ }^{8}$ In AD hippocampus, peptidyl prolyl cis-trans isomerase (PIN), phosphoglycerate mutase 1 , ubiquitin carboxyl terminal hydrolase 1 , DRP-2, carbonic anhydrase II, triose phosphate isomerase (TPI), $\alpha$-enolase, and $\gamma$-SNAP were identified as significantly oxidized proteins (Table 1). Reduced enzyme activities in $\mathrm{AD}$ hippocampus relative to control hippocampus were also found. However, no significantly oxidized proteins were identified in cerebellum compared with control, ${ }^{43}$ consistent with the lack of pathology in this brain region in $\mathrm{AD}$.

Nitric oxide (NO) has been implicated in the pathophysiology of a number of neurodegenerative diseases ${ }^{44}$ including AD. Our initial approach ${ }^{25}$ to identify modified proteins in $\mathrm{AD}$ inferior parietal lobe led to specific markers of nitrosylation, successfully detecting three targets of protein modification: neuropolypeptide $h 3$, triosephosphate isomerase (TPI), and $\alpha$-enolase ${ }^{10}$ (Table 1). Our newer redox proteomics approach ${ }^{25}$ identified enolase, glyceraldehyde-3-phosphate dehydrogenase (GAPDH), ATP synthase $\alpha$-chain, carbonic anhydrase-II, and voltage-dependent anion channel (VDAC) protein as the targets of nitration in AD hippocampus specifically (see Table 1), a region that shows an extensive deposition of amyloid beta-peptide, compared with the age-matched control brains.

Taken together, carbonylated and nitrated proteins in $\mathrm{AD}$ brain deal with energy metabolism, excitotoxicity, recycling of damaged or aggregated proteins through the proteasome, membrane structure, apoptosis, and neuronal communication, suggesting that these modifications might affect protein function (Table 1). $\mathrm{CK}$ and $\mathrm{GS}^{7}$ and the glutamate transporter EAAT2 ${ }^{21}$ were validated (by protein/enzyme activity assays) for their respective protein function to confirm the above results.

\section{Mild cognitive impairment}

MCI is generally referred to the transitional zone between normal cognitive function and early dementia or clinically probable AD. Oxidative stress plays a significant role in $\mathrm{AD}$ and is increased in the superior/middle temporal gyri of MCI subjects. ${ }^{45,46}$ Because $\mathrm{AD}$ involves hippocampal-resident memory dysfunction, we determined protein oxidation and identified the oxidized proteins in the hippocampus of MCI subjects using redox proteomics. We found that protein oxidation is significantly increased in the hippocampus of MCI subjects when compared with age- and gender-matched controls. The oxidatively modified proteins in MCI hippocampus were identified as alpha-enolase (ENO1), glutamine syn- 
TABLE 1. Redox Proteomics Identification of Oxidatively Modified Proteins in AD and AD Model

\begin{tabular}{|c|c|c|}
\hline & Oxidatively Modified Proteins & Function \\
\hline \multirow[t]{8}{*}{ Human AD } & $\begin{array}{l}\text { CK, TPI, } \alpha \text {-enolase, GAPDH, ATP-synthase } \\
\alpha \text {-chain, VDAC } \\
\text { Phosphoglycerate mutase- } 1\end{array}$ & Energy-related proteins \\
\hline & GS & Neurotransmitter related \\
\hline & UCLH-1 & Proteosome related \\
\hline & DRP-2 & Structural protein \\
\hline & Neuropolypeptide h3 & Cholinergic \\
\hline & Carbonic anhydrase-II & $\mathrm{pH}$ regulation \\
\hline & PIN-1 & $\begin{array}{l}\text { Cell cycle, } \mathrm{A} \beta \text { production, } \\
\text { Tau-phosphorylation }\end{array}$ \\
\hline & Gamma-SNAP & Vesicular transport \\
\hline \multirow{4}{*}{$\begin{array}{l}\text { Cell culture plus } \mathrm{A} \beta(1- \\
42)\end{array}$} & 14-3-3 zeta & Signal transduction \\
\hline & GAPDH & Energy related \\
\hline & Pyruvate kinase & Energy related \\
\hline & Malate dehydrogenase & Energy related \\
\hline $\begin{array}{l}\text { Synaptosomes plus } \\
\text { A } \beta(1-42)\end{array}$ & $\beta$-actin, GFAP, DRP-2 & Structural proteins \\
\hline \multirow[t]{6}{*}{ In vivo $\mathrm{A} \beta(1-42)$ models } & $\begin{array}{l}\text { Pyruvate dehydrogenase, GAPDH, } \\
\text { Phosphoglycerate mutase- } 1\end{array}$ & Energy related \\
\hline & GS & Neurotransmitter related \\
\hline & Tubulin chain $15 / \alpha, \beta$-actin, & Structural proteins \\
\hline & $\beta$-Synuclein & Structural proteins \\
\hline & $14-3-3$ zeta & Signal transduction \\
\hline & Chaperonin 60 & $\begin{array}{l}\text { Mitochondrial and } \\
\text { proteosome related }\end{array}$ \\
\hline
\end{tabular}

thetase (GLUL), pyruvate kinase M2 (PKM2), and peptidyl-prolyl cis-trans isomerase 1 (PIN1). ${ }^{47}$ Three of these proteins, ENO1, GLUL, and PIN1, also are oxidatively modified in the late stages of AD. The interacteome of these proteins indicates the functional involvement of energy metabolism, synaptic plasticity, mitogenesis, and proliferation. Therefore, oxidative inactivation of these proteins from human MCI brain may alter the above-mentioned cellular processes and lead to the development of AD from MCI. We conclude that protein oxidation plays a significant role in the development of $\mathrm{AD}$ from MCI and that the oxidative inactivation of specific proteins likely is involved in the progression of $\mathrm{AD}$ from MCI.

\section{IN VITRO AND IN VIVO EFFECTS OF AB(1-42)}

\section{$A \beta(1-42)$ in neuronal cell cultures}

The identification of specific proteins that are vulnerable to oxidative damage induced by $\mathrm{A} \beta(1-42)$ could contribute to our understanding of not only the role of $\mathrm{A} \beta(1-42)$ in the pathogenesis of $\mathrm{AD}$, but also provide insight into the mechanisms of neurodegeneration at the protein level in this disorder. We reported ${ }^{48}$ the redox proteomic identification of two proteins found to be oxidized significantly in neuronal cultures treated with $\mathrm{A} \beta(1-42)$, namely, $14-3-3 \zeta$ and GAPDH (Table 1). Both in vitro and in vivo upregulation of GSH by $\gamma$-glutamylcysteine ethyl ester (GCEE) has been shown to protect brain cells against peroxynitrite-mediated oxidative damage. $^{49}$ Additionally, previous studies from our laboratory have shown that pretreatment of neuronal cell cultures with $1 \mathrm{~mm}$ GCEE results in the upregulation of glutathione and protects neurons against $\mathrm{A} \beta(1-42)$-induced protein oxidation. ${ }^{48}$

\section{$\mathbf{A} \boldsymbol{\beta}(\mathbf{1 - 4 2 )}$ in synaptosomes}

Synapse loss is known to be an early pathological event in $\mathrm{AD}$ and incubation of synaptosomes with $\mathrm{A} \beta(1-$ 42) leads to the formation of protein carbonyls. ${ }^{50}$ Redox proteomics was performed to test the involvement of $\mathrm{A} \beta(1-42)$ in the oxidation of proteins from synaptosomes isolated from Mongolian gerbils. ${ }^{51} \mathrm{~A} \beta(1-42)$ treatment leads to oxidatively modified proteins, consistent with the notion that $\mathrm{A} \beta(1-42)$-induced oxidative stress plays an important role in neurodegeneration in AD brain. We identified $\beta$-actin, GFAP, and dihydropyrimidinase-related protein-2 as significantly oxidized in synaptosomes (Table 1) treated with A $\beta(1-42)$. Additionally, $\mathrm{H}^{+}$-transporting two-sector ATPase, syntaxin binding protein 1 , glutamate dehydrogenase, $\gamma$-actin, and elongation factor Tu were identified as increasingly carbonylated. $^{51}$

Actin microfilaments play a role in the neuronal membrane cytoskeleton by maintaining the distribution of 
membrane proteins and segregating axonal and dendritic proteins. ${ }^{52}$ Oxidation of actin can lead to loss of membrane cytoskeletal structure, decreased membrane fluidity, and trafficking of synaptic proteins. Moreover, actin is involved in the elongation of the growth cone, similar to DRP-2, and loss of function of actin could play a role in the loss of synapse and neuronal communication documented in AD. ${ }^{53}$ DRP-2 is involved in the formation of neuronal connections and, consequently, maintenance of neuronal communication. DRP-2 is oxidatively modified in $\mathrm{AD}^{9}$ and has been shown to have decreased expression in $\mathrm{AD}$ brain. ${ }^{54}$ The oxidation and impaired activity of DRP-2 could result in the shortened dendritic lengths reported in AD brains. ${ }^{55} \beta$-actin was found to be significantly oxidized in synaptosomes treated with $\mathrm{A} \beta(1-42)$ consistent with its reported oxidation in $\mathrm{AD}$ brain. ${ }^{56}$

Protein oxidation has been shown to lead to protein conformational changes ${ }^{57,58}$ and loss of protein function. ${ }^{7,59}$ Based on this notion, oxidation and subsequent loss of function of the proteins identified in this study ${ }^{51}$ would lead to excitotoxicity, disruption of the synapse, and impairment of energy metabolism, all of which are implicated in AD.

\section{$\mathrm{A} \beta(1-42)$ in vivo treatment in rats}

$\mathrm{A} \beta(1-42)$ has been shown to induce cholinergic dysfunction when injected into rat brain, a finding consistent with cholinergic deficits documented in $\mathrm{AD} .{ }^{60}$ In this regard, we used redox proteomics to examine the regional in vivo protein oxidation induced by $\mathrm{A} \beta(1-42)$ injected into the nucleus basalis magnocellularis (NBM) of rat brain compared with saline-injected control at 7 days postinjection. ${ }^{20}$ Glutamine synthetase and tubulin chain $15 / \alpha$ in the cortex region and $14-3-3 \zeta$ and chaperonin 60 (HSP60) in the NBM were identified as significantly oxidized. ${ }^{20}$ Oxidative modification of specific proteins was also detected in the hippocampus, where 14-3-3 $\zeta, \beta$-synuclein, pyruvate dehydrogenase, GAPDH, and phosphoglycerate mutase- 1 were identified (Table 1). ${ }^{20}$

14-3-3 proteins, which are highly expressed in brain, are involved in a number of cellular functions, including signal transduction, protein trafficking, and metabolism. ${ }^{61}$ 14-3-3 can regulate the target protein by acting as a bridge between two target proteins, altering the intrinsic catalytic activity of the target protein to protect it from proteolysis and dephosphorylation. ${ }^{62}$ A number of metabolic enzymes were found to be oxidized by $\mathrm{A} \beta(1-$ 42) consistent with altered energy metabolism in AD. ${ }^{63-65}$ These enzymes include GAPDH, pyruvate dehydrogenase (lipoamide dehydrogenase), and phosphoglycerate mutase 1 , which play pivotal roles in energy metabolism.

It is important to note that both forms of phosphoglycerate mutase 1 were found to be significantly oxidized in the hippocampus by $\mathrm{A} \beta(1-42)$. Additionally, decreased expression of phosphoglycerate mutase 1 has been reported in $\mathrm{AD} .{ }^{66}$ Loss of function of phosphoglycerate mutase 1 is consistent with altered glucose metabolism in $\mathrm{AD}^{67}$ and could lead to the accumulation of glycolytic intermediates, decreased production of pyruvate, and, consequently, decreased production and availability of ATP.

GS was also identified as a target of $\mathrm{A} \beta(1-42)$ induced protein oxidation. This finding is consistent with the oxidation and decreased activity of GS in AD brain. ${ }^{7,8} \mathrm{GS}$ is an enzyme that catalyzes the conversion of glutamate to glutamine. Loss of function of GS would result in the decreased conversion of glutamate, leading to the extracellular accumulation of glutamate. Excess glutamate could stimulate NMDA receptors leading to excitotoxicity and neuronal death, two factors that could play an important role in neurodegeneration and $\mathrm{AD}{ }^{68}$

Tubulin also exhibited a significant increase in protein oxidation after $\mathrm{A} \beta(1-42)$ exposure. Tubulin is a core protein of microtubules, which play a role in cytoskeletal maintenance. The oxidation of tubulin leading to loss of protein function could result in loss of neuronal connections and communication as well as compromised cellular structure, which would play important roles in neurodegeneration. $\beta$-synuclein normally plays a role in synaptic vesicle homeostasis. In rat brain, $\beta$-synuclein has been shown to play a role in catecholaminergic components (particularly in the basal forebrain) of the CNS. ${ }^{69}$ In the current study, we found $\beta$-synuclein to be significantly oxidized by $\mathrm{A} \beta(1-42)$. If $\beta$-synuclein is involved in synapse formation within the cholinergic regions of the brain, loss of function due to oxidation could result in loss of synapses and cholinergic deficits documented in $\mathrm{AD}$. $53,70,71$

Chaperonin 60 (Cpn60), or heat shock protein 60 (HSP60), is a mitochondrial chaperone protein that is involved in mediating the proper folding and assembly of mitochondrial proteins, especially in response to oxidative stress. ${ }^{72}$ Additionally, HSP60 has been proposed to play a role as an antiapoptotic protein. ${ }^{73}$ We found HSP60 to be significantly oxidized by A $\beta(1-42)$. The loss of function of HSP60 could lead to increased protein misfolding and aggregation as well as an increased vulnerability to oxidative stress.

The results suggest that a single injection of $\mathrm{A} \beta(1-42)$ into NBM can have profound effects elsewhere in the brain and $\mathrm{A} \beta(1-42)$-induced oxidative stress in rat brain mirrors some of those proteins oxidized in AD brain. In summary, loss of function or altered function of these proteins due to conformation changes induced by oxidation could lead to the neurofibrillary tangle pathology, increased protein aggregation, excitotoxicity, loss of cytoskeletal integrity, loss of synapses, and altered energy 
TABLE 2. Summary of Proteomics-Identified Proteins in C. elegans Model (CL4176) That Expresses Human A (1-42)

\begin{tabular}{ll}
\hline \multicolumn{1}{c}{ Function } & \multicolumn{1}{c}{ Protein Name } \\
\hline Energy metabolism & $\begin{array}{l}\text { Medium-chain acyl-CoA dehydrogenase } \\
\text { Short-chain acyl-CoA dehydrogenase } \\
\text { Translation elongation factor EF-1 } \\
\text { Malate dehydrogenase } \\
\text { Arginine kinase }\end{array}$ \\
& $\begin{array}{l}\text { Myosin regulatory light chain } \\
\text { Myosin regulatory light chain }\end{array}$ \\
Structural proteins & Actin-b \\
& RACK1 ortholog \\
& Adenosine kinase \\
Signaling proteins & Lipid binding protein \\
& Transketolase \\
Lipid metabolism & Proteasome alpha subunit \\
& Proteasome beta subunit \\
Proteosome function & Glutathione $S$-transferase sigma class \\
Antioxidant related enzyme & Nematode specific protein \\
Others &
\end{tabular}

metabolism, all of which are associated with AD. Our findings are particularly important as they provide supporting evidence for the role of $\mathrm{A} \beta(1-42)$ as a mediator of oxidative stress in $\mathrm{AD}$ brain.

\section{$\mathrm{A} \beta(1-42)$ in vivo in Caenorhabditis elegans}

$\mathrm{A} \beta(1-42)$ has been proposed to play a central role in the oxidative stress evident in $\mathrm{AD} \cdot{ }^{35,41}$ However, little is known about the specific in vivo effects of $\mathrm{A} \beta(1-42)$, especially with respect to the specific protein targets of oxidation. Redox proteomics techniques were used to identify proteins that are specifically oxidatively modified in $C$. elegans expressing human $\mathrm{A} \beta(1-42)$. This model (CL4176) expresses intracellular $A \beta(1-42)^{74}$ and thus we have specifically identified intracellular targets of $\mathrm{A} \beta$ oxidation. We identified 16 oxidized proteins (Table 2$)^{74}$ involved in energy metabolism, cellular structure maintenance, lipid transport, proteasome function, signaling, and scavenging of oxidants that are more highly oxidized compared with control lines, consistent with functions found to be altered in AD brain. These results provide insight into the neurodegenerative effects of $\mathrm{A} \beta(1-42)$-induced protein oxidation in the pathogenesis of $\mathrm{AD}$.

\section{Gracile axonal dystrophy (GAD)}

The GAD mouse is an autosomal recessive spontaneous mutant with a deletion on chromosome 5 within the gene encoding ubiquitin carboxyl-terminal hydrolase L-1 (UCH L-1). The mouse displays region-specific axonal degeneration of the gracile tractl, which is important for conveying mechanosensory information from the lower extremities. UCH L-1 is a crucial enzyme for proteasomal protein degradation and one specific target of protein oxidation in AD brain. However, it is unclear how protein oxidation affects function. However, studies using this mouse could establish a link between the effect of oxidative stress on proteins and the proteasomal dysfunction in $\mathrm{AD}$. A redox proteomic study on the GAD mouse brain, with dysfunctional UCH L-1, was used to determine differences in brain protein oxidation levels between control and GAD samples. The results showed significantly increased protein oxidation in thioredoxin peroxidase (peroxiredoxin), phosphoglycerate mutase, Rab GDP dissociation inhibitor- $\alpha$ /ATP synthase, and neurofilament-L within the GAD mouse brain. ${ }^{75}$

Neurofilaments are axonal proteins that participate in the neuronal cytoskeletal structure and play an important role in the process of myelination. ${ }^{76}$ The hypothesis that neurofilaments might be a target of protein modification in motor neuron diseases is supported by extensive evidence. ${ }^{77-79}$ Thioredoxin peroxidases or peroxiredoxins are small redox proteins that act as antioxidants and catalyze the elimination of hydroperoxides through the reducing system thioredoxin/thioredoxin reductase. This enzyme is considered a strong defense against oxidative stress. Based on the loss of activity of other oxidatively modified brain proteins, ${ }^{7,80}$ the finding that thioredoxin peroxidase is a target of protein oxidation within the GAD mouse brain implies harmful consequences for neurons in this UCH L-1-altered mouse, owing to a dramatic decrease in cellular antioxidant capability. Phosphoglycerate mutase is the glycolytic enzyme responsible for the interconversion of 3-phosphoglycerate to 2-phosphoglycerate. Glycolytic enzymes and creatine kinase BB are oxidatively modified in AD brain, ${ }^{8-10,81}$ and this oxidation might contribute to the reduced glucose metabolism observed in AD brain. Rab GDP dissociation inhibitor- $\alpha$ and ATP synthase, which play a pivotal role in signaling and energy metabolism, respectively, were detected as a single spot on the GAD brain map and each play a pivotal role in signaling and energy metabolism, respectively. 


\section{SAMP8 MOUSE STUDIES}

\section{SAMP8 mouse model}

The senescence-accelerated prone mouse (SAMP) was created as a mouse model for aging in 1981. Five litters of AKR/J mice had shown signs of senility at an earlier age and a shorter lifespan, and they were selected as progenitors of the SAMP mice. ${ }^{82}$ The litters that did not show these characteristics were determined to be senescence-accelerated-resistant mice (SAMR); these mice are often used as a control for SAMP mice. ${ }^{82}$ There are nine major substrains of SAMP mice, which exhibit different disorder characteristics. ${ }^{83}$ The substrain of interest, SAMP8, is characterized as having age-related learning and memory deficits, anxiety, impaired immune system, and age-dependent deposition of $\mathrm{A} \beta{ }^{84}$ As such, this mouse may be a potential model for aspects of $\mathrm{AD}{ }^{85}$

SAMP8 mice are a good model for cognitive impairment in aging because their development of learning and memory deficits is not complicated with other phenotypic implications of aging. ${ }^{84}$ Aged SAMP8 mice compared with SAMR1 mice show difficulty in learning tasks and increased oxidative stress. ${ }^{80}$ When studying young versus old SAMP8 mice a correlation between learning and oxidative damage was demonstrated. ${ }^{84,86}$ These studies support the free radical theory of aging, demonstrating an increase in reactive oxygen species (ROS) as a source of oxidative modifications to biomolecules, in turn causing cellular dysfunction in aging.

Redox proteomics was used to compare the expression and oxidative modifications that differ between young (4 month) and old (12 month) SAMP8 mice. ${ }^{87}$ The analysis of protein expression using proteomics identified a significant increase in expression of triosephosphate isomerase (TPI), but a significant decrease in expression of neurofilament triplet L protein (NF-L), lactate dehydrogenase 2 (LDH-2), heat shock protein 86 (HSP86), and $\alpha$-spectrin in the brain of the old SAMP8 mice. An analysis of the carbonylated proteins demonstrated a significant increase in carbonyl levels of $\alpha$-enolase, LDH-2, creatine kinase (CK), dihydropyrimidinase-like protein 2 (DRP-2), and $\alpha$-spectrin. ${ }^{87}$ The alterations of DRP-2, $\alpha$-spectrin, and NF-L indicate potential alterations in cell signaling, intracellular trafficking, and maintenance of neuronal structure. These changes could be relevant to the known memory and learning deficits in the aged SAMP8 mouse. ${ }^{88}$ Reduced activity in proteins involved in energy and metabolism such as TPI, $\alpha$-enolase, and CK could be related to the known reduced glucose metabolism and ATP production in the aged SAMP 8 mouse. ${ }^{89}$ TPI, HSP, $\alpha$-enolase, CK, and DRP-2 have also been found oxidatively modified in AD brain, ${ }^{43}$ showing again a potential link between the SAMP8 mouse model and $\mathrm{AD}$.

\section{$\alpha$-lipoic acid treatment of aged SAMP8 mice}

Because of the increase in oxidative damage seen in the aged SAMP8 mouse, the effects of antioxidant treatment were determined. A known antioxidant, $\alpha$-lipoic acid (LA), is a coenzyme involved in the production of ATP in the mitochondria. ${ }^{90,91}$ LA has previously shown ability to act as an ROS scavenger, to chelate metals, and to recycle endogenous antioxidants. ${ }^{92-94}$ LA was used to treat the aged SAMP8 mouse, reducing the overall oxidative damage as well as oxidation to specific proteins. ${ }^{34}$ The mice were treated for 1 week subcutaneously with LA $(100 \mathrm{mg} / \mathrm{kg})$ daily. The LA-treated mice exhibited an overall reduction in protein carbonyls and an increase in performance on the T-maze footshock avoidance paradigm, similar to the behavior of young SAMP8 mice.

Redox proteomics was employed to identify specific proteins altered by the treatment of LA in comparison to untreated aged SAMP8 mice. ${ }^{34}$ An increase in expression was found in NF-L, $\alpha$-enolase, and ubiquitous mitochondrial creatine kinase (uMiCK). A significant reduction in carbonylation of the proteins LDH-2, DRP-2, and $\alpha$-enolase was also demonstrated. Both NF-L and $\alpha$-enolase were found to have a decreased expression in old SAMP8 mice compared with young SAMP8 mice and this was reversed with the treatment of LA. ${ }^{87}$ All of the proteins found to have a significant decrease in carbonylation from the treatment of LA were found to be specifically increased in the aged untreated SAMP8 mouse. ${ }^{34,87}$ This correlation indicates that LA is sensitive to the proteins undergoing oxidative damage and its antioxidant and biological properties modulate oxidative post-translational modification of proteins. Many neurodegenerative disorders are characterized by conformational changes in proteins that result in misfolding, aggregation, and intra- or extraneuronal accumulation of amyloid fibrils. Effective therapeutic strategies for cellular repair based on misfolded proteins have been developed. ${ }^{95,96}$

\section{Administration of A $\beta$-directed antisense oligonucleotide in SAMP8 mice}

Previous studies have shown that the SAMP8 mouse has an increased expression of amyloid precursor protein $(A P P)$ and about and an approximate $100 \%$ increase of $\mathrm{A} \beta$ in the brain. ${ }^{97}$ An increase in $\mathrm{A} \beta$ has also been shown to increase oxidative stress, which has been reported in the SAMP8 mouse. ${ }^{35,36,39,86}$ The use of an antisense oligonucleotide targeted to bind to the $\mathrm{A} \beta$ region of APP mRNA was proposed to reduce the production of $\mathrm{A} \beta$ at the translational level and therefore ameliorate the oxidative damage caused by $\mathrm{A} \beta .^{98}$

The SAMP8 mice underwent three intracebroventricular (ICV) injections at 2-week intervals of the targeted antisense oligonucleotide (AO) or the random oligonucleotide (RO), which was used as a control. ${ }^{98}$ The level 
of $\mathrm{A} \beta$ in the brain was reduced by greater than $40 \%$ with the treatment of AO compared with the AR treatment. The amount of $\mathrm{A} \beta$ in brain after the $\mathrm{AO}$ treatment to the aged SAMP8 mouse was similar to the $A \beta$ in the young SAMP8 mouse. ${ }^{98}$ The overall protein carbonyl level was also reduced by approximately $20 \%$. Redox proteomics was then used to identify the specific proteins protected from protein carbonylation by AO. ${ }^{98}$ The protein carbonyl levels of Aldose 3 (Aldo3), Coronin 1a (Coro1a), and Peroxiredoxin $2(\operatorname{Prd} \times 2)$ were reduced by the treatment of AO. Aldo3 is a glycolytic enzyme that interacts with DRP-2 in response to oxidative stress ${ }^{99}$ and has been implicated in aging. Corola is an actin binding protein $^{100}$ and is reduced in Down's syndrome. Prdx 2 is specific to neurons ${ }^{101}$ and works as an antioxidant enzyme modulating intracellular hydrogen peroxide. ${ }^{102}$ The protection of these enzymes increases the brain's ability to maintain structure and its delicate oxidative balance.

\section{OTHER RODENT MODELS OF AGE- RELATED NEURODEGENERATIVE DISEASES}

\section{Amyotrophic lateral sclerosis}

Amyotrophic lateral sclerosis, commonly known as Lou Gehrig's disease, is a progressive neurodegenerative disease that affects the nerve cells of the CNS. The progressive degeneration of the motor neurons in ALS eventually leads to death within 3 to 5 years after disease diagnosis. ${ }^{103}$ The brain's ability to control muscle movement is extremely limited and, since voluntary muscle action is progressively affected, patients in later stages of the disease may become totally paralyzed. There are several different familial and sporadic types of ALS, with sporadic ALS the most common form in the United States, consisting of $90-95 \%$ of all cases. Familial ALS accounts for a very small number of cases in the United States. The biggest factor contributing to familial ALS is thought to be a mutation in the SOD1 gene. ${ }^{104}$ This particular gene encodes for the important enzyme, $\mathrm{Cu} / \mathrm{Zn}$ superoxide dismutase (SOD). $\mathrm{Cu} / \mathrm{Zn}-\mathrm{SOD}$ is one of the four types of superoxide dismutases. MnSOD, NiSOD, and FeSOD are the other three. CuZn-SOD is an enzyme that converts superoxide to hydrogen peroxide and oxygen. There are hundreds of missense mutations in SOD1 that can occur in ALS, ${ }^{105}$ but one of the most common mutations is the substitution of Gly93 $\rightarrow$ Ala. ${ }^{105}$ The Gly93 $\rightarrow$ Ala transgenic mouse model is a useful model for studying ALS because of similar neuropathy in the animal model and the human. ${ }^{106}$ Through a proteomics approach, researchers have shown that several proteins were found to be oxidatively modified in the Gly93 $\rightarrow$ Ala transgenic mouse model, including SOD1, translationally controlled tumor protein (TCTP), ubiquitin carboxyterminal hydrolase-L1 (UCH-L1), and $\alpha$ B-crystallin. ${ }^{107}$
In immunoprecipitation studies, SOD1 was shown to be oxidatively modified in the spinal cord of the Gly93 $\rightarrow$ Ala. ${ }^{108}$ TCTP is involved in calcium binding and this could be a contributing factor to the increase of free calcium in ALS patient lymphocytes. ${ }^{109}$ Additionally, elevated cytosolic $\mathrm{Ca}^{2+}$ levels likely contribute to mitochondrial dysfunction in ALS. ${ }^{110}$

As noted above, UCH-L1 is an ubiquitin carboxyterminal hydroxylase involved in the ubiquitin proteasome pathway. ${ }^{111}$ Polyubiquitinated proteins are degraded by the $26 \mathrm{~S}$ proteosome and this protein was found to be oxidatively modified in $\mathrm{AD}$ brain. ${ }^{8} \alpha \mathrm{B}$-crystallin acts as a molecular chaperone, which prevents protein misfolding in stress conditions. ${ }^{112}$ These above-mentioned proteins were all found to be upregulated in the transgenic SOD animal compared with control. All of the proteins identified, with the exception of TCTP, were also located to the inclusions found ALS patients and recapitulated in mouse models. In a similar investigation, through redox proteomics, several HNE-bound proteins from the spinal cord were also identified, including DRP-2, heat shock protein 70 (Hsp70), and $\alpha$-enolase. ${ }^{113}$

As noted previously, DRP-2 is a protein involved in neuronal communication and axonal outgrowth. This protein has shown to be oxidatively modified in $\mathrm{AD}$ brain. ${ }^{9}$ Heat shock protein 70 is in the heat shock family of proteins that acts as a molecular chaperone in protein misfolding and response due to stress. Research has shown that Hsp70 plays a role in prevention of SOD1 aggregate formation and folding. ${ }^{114} \alpha$-enolase is an important protein involved in energy metabolism and is the enzyme that catalyzes the dehydration of 2-phosphoglycerate to phosphoenolpyruvate, thereby producing ATP in glycolysis.

\section{Parkinson's disease}

Parkinson's disease is a neurodegenerative disease affecting roughly $1 \%$ of individuals over the age of 65 . The majority of PD cases are likely sporadic but there are a number of rare, genetic causes of this disease. Under normal circumstances, the neurotransmitter dopamine binds to dopaminergic receptors in the brain to support muscle movement and coordination. The loss of dopaminergic cells appears to underlie a depletion of cellular dopamine and an elevation in excitatory movements. ${ }^{115}$ In PD, patients have a loss of dopaminergic neurons in the substantia nigra region of the brain and the formation of Lewy bodies, which contain a number of proteins, of which $\alpha$-synuclein is the major component. Aggregation of $\alpha$-synuclein leads to neurotoxicity. ${ }^{5}$

$\alpha$-synuclein is a protein that aids in neuronal communication and presynaptic vesicle associated functions. ${ }^{116}$ Synaptic vesicle depletion correlates with attenuated synaptic responses to prolonged repetitive stimulation in mice lacking alpha-synuclein. ${ }^{117} \alpha$-synuclein can form 
aggregates, which can accelerate cell toxicity. Research has shown that $\alpha$-synuclein is associated with inherited forms of PD. ${ }^{118}$ Proteomics has identified two proteins to be oxidatively modified in the substantia nigra of animal model of Parkinson's disease: $\alpha$-enolase and $\beta$-actin. ${ }^{119}$ These two proteins in particular were also found to be oxidatively modified and nitrated in $\mathrm{AD}$ brain. ${ }^{8,10,120}$ $\alpha$-enolase is important in energy metabolism and ATP production, while $\beta$-actin is an isoform of actin, which is a cytoskeletal protein used in microfilament assembly. Other proteins found to have modifications in certain cases of familial PD include UCH-L1, which is essential in the ubiquitin proteosome pathway and the degradation of aggregated and defective proteins, and the recycling of ubiquitin; ${ }^{121}$ DJ-1 (PARK7), which can act as an antioxidant in overexpressing animals; ${ }^{122}$ PINK1, (PARK6), which serves as a mitochondrial protein kinase; ${ }^{123}$ and parkin (PARK2), which acts as a E3 ligase in the ubiquitin proteosome pathway and is a cofactor in juvenile recessive $\mathrm{PD} .{ }^{124}$

Mutations in $\alpha$-synuclein cause familial PD, and overexpressing mutant human- $\alpha$-synuclein (A30P or A53T) causes degenerative disease in mouse and Drosophila models. ${ }^{125}$ The pathophysiology of PD is poorly understood, but increasing evidence implicates mitochondrial dysfunction and oxidative stress. To understand how mutations in $\alpha$-synuclein contribute to the pathophysiology of $\mathrm{PD}$, we undertook a proteomic analysis of transgenic mice overexpressing $\mathrm{A} 30 \mathrm{P} \alpha$-synuclein to investigate which proteins were oxidized. We observed selective increases in specific carbonyl levels of three metabolic proteins in brains of symptomatic A30P $\alpha$-synuclein mice: carbonic anhydrase 2 (Car2), $\alpha$-enolase (Eno1), and lactate dehydrogenase $2(\mathrm{Ldh} 2) .{ }^{126}$ Analysis of the activities of these proteins demonstrates decreased functions of these oxidatively modified proteins in brains from the A30P mutant mice compared with control mice. ${ }^{126}$ Our findings suggest that proteins associated with impaired energy metabolism and mitochondria are particularly prone to oxidative stress associated with A30P-mutant $\alpha$-synuclein.

\section{Huntington's disease}

Huntington's disease is a neurodegenerative disease resulting from the genetically programmed degeneration of neurons in the striatum. This pathology causes uncontrolled movements (chorea), loss of intellectual faculties, and emotional disturbances. ${ }^{127}$ The genetic basis of HD is the expansion of a CAG repeat encoding a polyglutamine tract in the $\mathrm{N}$-terminus of the protein product called huntingtin, the function of which is unknown. ${ }^{128}$ The association of huntingtin with the cytoplasmic surface of a variety of organelles, including transport vesicles, synaptic vesicles, microtubules, and mitochondria, raises the possibility of the occurrence of abnormal cel- lular interactions that might be relevant to neurodegeneration. Earlier studies suggest that the huntingtin protein may interact with GAPDH in glycolysis. ${ }^{129}$ Glyceraldehyde-3-phosphate dehydrogenase is the enzyme in glycolysis that converts glyceraldyhyde-3-phosphate to 1,3bisphosphoglycerate. Diverse properties of GAPDH include proposed roles in membrane transport, membrane fusion, microtubule bundling, phosphotransferase activity, nuclear RNA export, DNA replication, and DNA repair. Thus, as a tetramer in the cytoplasm, GAPDH functions in glycolysis or as an RNA binding protein. In contrast, as a monomer in the nucleus, GAPDH functions in DNA repair. The subcellular localization of GAPDH appears to be tightly regulated both during proliferation and during apoptosis. ${ }^{130,131}$

3-nitropropionic acid (3-NP) is a Complex II inhibitor in mitochondria, which causes damage to the succinate dehydrogenase enzyme of the electron transport chain and Kreb's cycle. ${ }^{132}$ Intraperitoneal injections of 3-nitropropionic acid leads to protein oxidative damage before striatal lesion formation, providing insight into HD. ${ }^{133}$ The glutathione increasing agent, $N$-acetylcysteine, ${ }^{134}$ can combat 3-NP treatment by effectively elevating glutathione antioxidant levels, thus reducing 3-NP toxicity in rodents. ${ }^{133}$ Current research in proteomics related to Huntington's disease shows that in the R6/2 Tg mouse model of HD (which expresses exon 1 of the human HD gene with an expanded CAG trinucleotide repeat of around $150 \mathrm{U}$ ), the brain proteins $\alpha$-enolase, $\gamma$-enolase, aconitase, Hsp90, creatine kinase, and voltage-dependent gated anionic channel-1 (VDAC1), were oxidatively modified. ${ }^{135} \alpha$-enolase has been found to be oxidatively modified in AD, ALS, PD, and HD, indicating that energy metabolism is involved in all four neurodegenerative diseases. $\gamma$-enolase is an isoform of enolase that also is involved in energy metabolism and cell differentiation. Aconitase catalyzes the isomerization of citrate to isocitrate. Hsp90 is in the family of heat shock proteins that acts as molecular chaperones for misfolding proteins. Creatine kinase is essential in energy production acting as an enzyme in converting creatine to phosphocreatine and is also found to be oxidatively modified in $\mathrm{AD}{ }^{8}$ VDAC is affected in AD. ${ }^{136}$ VDAC 1 acts as a gate in the permeability transition pore in maintaining the balance of $\mathrm{Ca}^{2+}$ levels in the cell. Impairment of this protein can cause disruption of $\mathrm{Ca}^{2+}$ homeostasis and lead to excitotoxicity.

5-diethoxyphosphoryl-5-methyl-1-pyrroline- $\mathrm{N}$-oxide, better known as DEMPO, has been found to significantly decrease the amount of protein oxidation in 3-NP-injected rats and prevent striatal lesion formation. Also DMPO, the nonphosphorylated form of DEMPO, acts as an antioxidant against 3-NP. ${ }^{133}$ Creatine and acetyl-Lcarnitine have been found to decrease oxidative damage to 3-NP-treated samples. ${ }^{137}$ 


\section{CONCLUSION}

Protein profiling technologies have provided the tools for researchers to identify the dynamics of biological pathways of disease states at the molecular level. There are vast areas of translational investigations concerning neurodegenerative diseases where potential markers and correlated proteins can be identified. The goal is to understand the disease and to elucidate the underlying disorder at a molecular level. Redox proteomic approaches extend perspectives for proteomic-driven research aimed at unraveling mechanisms of neurodegenerative diseases. Unlike inborn errors of metabolism, neurodegenerative disorders are often multigenic, and the quest involves correlating symptoms to their molecular bases and better understanding of disease to assist in drug discovery. Insights into multifactorial disease processes may lead to the accelerated acquisition of new therapeutic targets. Understanding the underlying molecular mechanisms with respect to altered signaling cascades may provide insights into neuropathological disorders. Redox proteomics is an emerging technique that identifies oxidatively modified proteins in neurodegeneration. Protein oxidation has been shown to induce conformational changes leading to loss of protein function. Restoration of protein function by use of CNS-accessible antioxidants that also possess the ability to induce protective genes and downregulate harmful genes may help in the recovery from oxidative stress and may be consequently beneficial for the improvement of learning and memory in neurodegenerative diseases. In clinical trials molecules with antioxidant properties such as vitamin $\mathrm{E}$ and Ginkgo biloba extract have shown modest benefit. A clinical trial with vitamin E recently demonstrated no delay in the progression to AD in individuals with mild cognitive impairment. However, no vitamin $\mathrm{C}$ to restore vitamin $\mathrm{E}$ function was included in this trial. Combinations of antioxidants might be of even greater potential benefit, especially if the agents worked in different cellular compartments or had complementary activity (e.g., vitamins E, C, and ubiquinone). Naturally occurring compounds with antioxidant capacity are available and widely marketed (e.g., vitamin $\mathrm{C}$, ubiquinone, lipoic acid, acetyl-L-carnitine, $\beta$-carotene, creatine, melatonin, curcumin, and ferulic acid) and synthetic compounds are under development by industry. Despite its current limitations, proteomics is one of the most promising approaches for providing clues on the molecular basis of neurodegenerative diseases that may lead to the discovery of potential therapeutic targets and hence new therapeutic molecules to treat these devastating disorders.

Acknowledgments: This work was supported in part by Grants AG-10836 and AG-05119 from the National Institutes of Health.

\section{REFERENCES}

1. Selkoe DJ. Alzheimer's disease results from the cerebral accumulation and cytotoxicity of amyloid $\beta$-protein. J Alzheimers Dis 3:75-80, 2001.

2. Cruts M, van Broeckhoven C. Presenilin mutations in Alzheimer's disease. Hum Mutat 11:183-190, 1998.

3. Slooter AJ, Cruts M, Kalmijn S, Hofman A, Breteler MM, van Broeckhoven $\mathrm{C}$, et al. Risk estimates of dementia by apolipoprotein E genotypes from a population-based incidence study: the Rotterdam Study. Arch Neurol 55:964-968, 1998.

4. Olanow CW, Tatton WG. Etiology and pathogenesis of Parkinson's disease. Annu Rev Neurosci 22:123-144, 1999.

5. Gandhi S, Wood NW. Molecular pathogenesis of Parkinson's disease. Hum Mol Genet 14:2749-2755, 2005.

6. Kurosinski P, Guggisberg M, Gotz J. Alzheimer's and Parkinson's disease: overlapping or synergistic pathologies? Trends $\mathrm{Mol}$ Med 8:3-5, 2002

7. Hensley K, Hall N, Subramaniam R, Cole P, Harris M, Aksenov $\mathrm{M}$, et al. Brain regional correspondence between Alzheimer's disease histopathology and biomarkers of protein oxidation. J Neurochem 65:2146-2156, 1995.

8. Castegna A, Aksenov M, Aksenova M, Thongboonkerd V, Klein JB, Pierce WM, et al. Proteomic identification of oxidatively modified proteins in Alzheimer's disease brain. Part I: creatine kinase BB, glutamine synthase, and ubiquitin carboxy-terminal hydrolase L-1. Free Radic Biol Med 33:562-571, 2002.

9. Castegna A, Aksenov M, Thongboonkerd V, Klein JB, Pierce WM, Booze R, et al. Proteomic identification of oxidatively modified proteins in Alzheimer's disease brain. Part II: dihydropyrimidinase-related protein $2, \alpha$-enolase and heat shock cognate 71 . $J$ Neurochem 82:1524-1532, 2002.

10. Castegna A, Thongboonkerd V, Klein JB, Lynn B, Markesbery WR, Butterfield DA. Proteomic identification of nitrated proteins in Alzheimer's disease brain. J Neurochem 85:1394-1401, 2003.

11. Cleary JP, Walsh DM, Hofmeister JJ, Shankar GM, Kuskowski MA, Selkoe DJ, et al. Natural oligomers of the amyloid- $\beta$ protein specifically disrupt cognitive function. Nat Neurosci 8:79-84, 2005.

12. Klein WL, Stine WB Jr, Teplow DB. Small assemblies of unmodified amyloid $\beta$-protein are the proximate neurotoxin in Alzheimer's disease. Neurobiol Aging 25:569-580, 2004.

13. Markesbery WR. Oxidative stress hypothesis in Alzheimer's disease. Free Radic Biol Med 23:134-147, 1997.

14. Boyd-Kimball D, Sultana R, Mohmmad-Abdul H, Butterfield DA. Rodent $A \beta(1-42)$ exhibits oxidative stress properties similar to those of human $A \beta(1-42)$ : implications for proposed mechanisms of toxicity. J Alzheimers Dis 6:515-525, 2004.

15. Sultana R, Ravagna A, Mohmmad-Abdul H, Calabrese V, Butterfield DA. Ferulic acid ethyl ester protects neurons against amyloid $\beta$-peptide(1-42)-induced oxidative stress and neurotoxicity: relationship to antioxidant activity. J Neurochem 92:749758, 2005.

16. Drake J, Link CD, Butterfield DA. Oxidative stress precedes fibrillar deposition of Alzheimer's disease amyloid $\beta$-peptide( $1-$ $42)$ in a transgenic Caenorhabditis elegans model. Neurobiol Aging 24:415-420, 2003.

17. Yatin SM, Varadarajan S, Link CD, Butterfield DA. In vitro and in vivo oxidative stress associated with Alzheimer's amyloid $\beta$-peptide(1-42). Neurobiol Aging 20:325-330; discussion 339342, 1999.

18. Mohmmad Abdul H, Sultana R, Keller JN, St Clair DK, Markesbery WR, Butterfield DA. Mutations in amyloid precursor protein and presenilin-1 genes increase the basal oxidative stress in murine neuronal cells and lead to increased sensitivity to oxidative stress mediated by amyloid $\beta$-peptide(1-42), HO and kainic acid: implications for Alzheimer's disease. J Neurochem 96:1322-1335, 2006.

19. Mohmmad Abdul H, Wenk GL, Gramling M, Hauss-Wegrzyniak B, Butterfield DA. APP and PS-1 mutations induce brain oxidative stress independent of dietary cholesterol: implications for Alzheimer's disease. Neurosci Lett 368:148-150, 2004.

20. Boyd-Kimball D, Sultana R, Poon HF, Lynn BC, Casamenti F, 
Pepeu G, et al. Proteomic identification of proteins specifically oxidized by intracerebral injection of amyloid $\beta$-peptide(1-42) into rat brain: implications for Alzheimer's disease. Neuroscience 132:313-324, 2005.

21. Lauderback CM, Hackett JM, Huang FF, Keller JN, Szweda LI, Markesbery WR, et al. The glial glutamate transporter, GLT-1, is oxidatively modified by 4-hydroxy-2-nonenal in the Alzheimer's disease brain: the role of A $\beta 1-42$. J Neurochem 78:413-416, 2001.

22. Markesbery WR, Lovell MA. Four-hydroxynonenal, a product of lipid peroxidation, is increased in the brain in Alzheimer's disease. Neurobiol Aging 19:33-36, 1998.

23. Mariani E, Polidori MC, Cherubini A, Mecocci P. Oxidative stress in brain aging, neurodegenerative and vascular diseases: an overview. J Chromatogr B Analyt Technol Biomed Life Sci 827: 65-75, 2005.

24. Butterfield DA, Kanski J. Brain protein oxidation in age-related neurodegenerative disorders that are associated with aggregated proteins. Mech Ageing Dev 122:945-962, 2001.

25. Butterfield DA. Proteomics: a new approach to investigate oxidative stress in Alzheimer's disease brain. Brain Res 1000:1-7, 2004.

26. Choe LH, Dutt MJ, Relkin N, Lee KH. Studies of potential cerebrospinal fluid molecular markers for Alzheimer's disease. Electrophoresis 23:2247-2251, 2002.

27. Rabilloud $\mathrm{T}$. Two-dimensional gel electrophoresis in proteomics: old, old fashioned, but it still climbs up the mountains. Proteomics 2:3-10, 2002.

28. Tilleman K, Stevens I, Spittaels K, Haute CV, Clerens S, Van Den Bergh G, et al. Differential expression of brain proteins in glycogen synthase kinase-3 transgenic mice: a proteomics point of view. Proteomics 2:94-104, 2002.

29. Smolka MB, Zhou H, Purkayastha S, Aebersold R. Optimization of the isotope-coded affinity tag-labeling procedure for quantitative proteome analysis. Anal Biochem 297:25-31, 2001.

30. Zhang J, Goodlett DR, Quinn JF, Peskind E, Kaye JA, Zhou Y, et al. Quantitative proteomics of cerebrospinal fluid from patients with Alzheimer's disease. J Alzheimers Dis 7:125-133; discussion 173-180, 2005.

31. Merchant M, Weinberger SR. Recent advancements in surfaceenhanced laser desorption/ionization-time of flight-mass spectrometry. Electrophoresis 21:1164-1177, 2000.

32. Seibert V, Wiesner A, Buschmann T, Meuer J. Surface-enhanced laser desorption ionization time-of-flight mass spectrometry (SELDI TOF-MS) and ProteinChip technology in proteomics research. Pathol Res Pract 200:83-94, 2004.

33. Hoogland C, Sanchez JC, Tonella L, Binz PA, Bairoch A, Hochstrasser DF, et al. The 1999 SWISS-2DPAGE database update. Nucleic Acids Res 28:286-288, 2000.

34. Poon HF, Farr SA, Thongboonkerd V, Lynn BC, Banks WA, Morley JE, et al. Proteomic analysis of specific brain proteins in aged SAMP8 mice treated with $\alpha$-lipoic acid: implications for aging and age-related neurodegenerative disorders. Neurochem Int 46:159-168, 2005.

35. Butterfield DA, Kanski J. Methionine residue 35 is critical for the oxidative stress and neurotoxic properties of Alzheimer's amyloid $\beta$-peptide 1-42. Peptides 23:1299-1309, 2002.

36. Butterfield DA, Lauderback CM. Lipid peroxidation and protein oxidation in Alzheimer's disease brain: potential causes and consequences involving amyloid $\beta$-peptide-associated free radical oxidative stress. Free Radic Biol Med 32:1050-1060, 2002.

37. Smith MA, Richey Harris PL, Sayre LM, Beckman JS, Perry G. Widespread peroxynitrite-mediated damage in Alzheimer's disease. J Neurosci 17:2653-2657, 1997.

38. Lovell MA, Markesbery WR. Ratio of 8-hydroxyguanine in intact DNA to free 8-hydroxyguanine is increased in Alzheimer's disease ventricular cerebrospinal fluid. Arch Neurol 58:392-396, 2001.

39. Varadarajan S, Yatin S, Aksenova M, Butterfield DA. Rew: Alzheimer's amyloid $\beta$-peptide-associated free radical oxidative stress and neurotoxicity. J Struct Biol 130:184-208, 2000.

40. Yatin SM, Varadarajan S, Butterfield DA. Vitamin E prevents Alzheimer's amyloid $\beta$-peptide(1-42)-induced neuronal protein oxidation and reactive oxygen species production. $J$ Alzheimers Dis 2:123-131, 2000.

41. Butterfield DA, Drake J, Pocernich C, Castegna A. Evidence of oxidative damage in Alzheimer's disease brain: central role for amyloid $\beta$-peptide. Trends Mol Med 7:548-554, 2001.

42. Bollard ME, Stanley EG, Lindon JC, Nicholson JK, Holmes E. NMR-based metabonomic approaches for evaluating physiological influences on biofluid composition. NMR Biomed 18:143$162,2005$.

43. Sultana R B-KD, Poon HF, Cai J, Pierce WM, Klein JB, et al Redox proteomics identification of oxidized proteins in Alzheimer's disease hippocampus and cerebellum: an approach to understand pathological and biochemical alterations in AD. Neurobiol Aging DOI:10.1016/j.neurobiolaging. 2005.05.005

44. Schulz JB, Matthews RT, Beal MF. Role of nitric oxide in neurodegenerative diseases. Curr Opin Neurol 8:480-486, 1995.

45. Keller JN, Schmitt FA, Scheff SW, Ding Q, Chen Q, Butterfield DA, et al. Evidence of increased oxidative damage in subjects with mild cognitive impairment. Neurology 64:1152-1156, 2005.

46. Butterfield DA, Reed T, Perluigi M, De Marco C, Coccia R, Cini $\mathrm{C}$, et al. Elevated protein-bound levels of the lipid peroxidation product, 4-hydroxy-2-nonenal, in brain from persons with mild cognitive impairment. Neurosci Lett 397:170-173, 2006.

47. Butterfield DA, Poon HF, St Clair D, Keller JN, Pierce WM, Klein JB, et al. Redox proteomics identification of oxidatively modified hippocampal proteins in mild cognitive impairment: insights into the development of Alzheimer's disease. Neurobiol Dis 22:223-232, 2006.

48. Boyd-Kimball D, Sultana R, Abdul HM, Butterfield DA. $\gamma$-glutamylcysteine ethyl ester-induced up-regulation of glutathione protects neurons against $\mathrm{A} \beta(1-42)$-mediated oxidative stress and neurotoxicity: implications for Alzheimer's disease. J Neurosci Res 79:700-706, 2005.

49. Drake J, Kanski J, Varadarajan S, Tsoras M, Butterfield DA. Elevation of brain glutathione by $\gamma$-glutamylcysteine ethyl ester protects against peroxynitrite-induced oxidative stress. J Neurosci Res 68:776-784, 2002

50. Butterfield DA, Hensley K, Harris M, Mattson M, Carney J. $\beta$-amyloid peptide free radical fragments initiate synaptosomal lipoperoxidation in a sequence-specific fashion: implications to Alzheimer's disease. Biochem Biophys Res Commun 200:710$715,1994$.

51. Boyd-Kimball D, Castegna A, Sultana R, Poon HF, Petroze R, Lynn BC, et al. Proteomic identification of proteins oxidized by A $\beta(1-42)$ in synaptosomes: implications for Alzheimer's disease. Brain Res 1044:206-215, 2005.

52. Beck KA, Nelson WJ. The spectrin-based membrane skeleton as a membrane protein-sorting machine. Am J Physiol (Lond) 270: C1263-C1270, 1996.

53. Masliah E, Mallory M, Hansen L, DeTeresa R, Alford M, Terry $R$. Synaptic and neuritic alterations during the progression of Alzheimer's disease. Neurosci Lett 174:67-72, 1994.

54. Lubec G, Nonaka M, Krapfenbauer K, Gratzer M, Cairns N, Fountoulakis M. Expression of the dihydropyrimidinase related protein 2 (DRP-2) in Down syndrome and Alzheimer's disease brain is downregulated at the mRNA and dysregulated at the protein level. J Neural Transm Suppl 57:161-177, 1999.

55. Coleman PD, Flood DG. Neuron numbers and dendritic extent in normal aging and Alzheimer's disease. Neurobiol Aging 8:521$545,1987$.

56. Aksenov MY, Aksenova MV, Butterfield DA, Geddes JW, Markesbery WR. Protein oxidation in the brain in Alzheimer's disease. Neuroscience 103:373-383, 2001.

57. Lauderback CM, Kanski J, Hackett JM, Maeda N, Kindy MS, Butterfield DA. Apolipoprotein E modulates Alzheimer's A $\beta(1-$ 42)-induced oxidative damage to synaptosomes in an allele-specific manner. Brain Res 924:90-97, 2002.

58. Subramaniam R, Roediger F, Jordan B, Mattson MP, Keller JN, Waeg G, et al. The lipid peroxidation product, 4-hydroxy-2-transnonenal, alters the conformation of cortical synaptosomal membrane proteins. J Neurochem 69:1161-1169, 1997. 
59. Hamos JE, DeGennaro LJ, Drachman DA. Synaptic loss in Alzheimer's disease and other dementias. Neurology 39:355-361, 1989.

60. Harkany T, O’Mahony S, Keijser J, Kelly JP, Konya C, Borostyankoi ZA, et al. $\beta$-amyloid(1-42)-induced cholinergic lesions in rat nucleus basalis bidirectionally modulate serotonergic innervation of the basal forebrain and cerebral cortex. Neurobiol Dis 8:667-678, 2001

61. Dougherty MK, Morrison DK. Unlocking the code of 14-3-3. J Cell Sci 117:1875-1884, 2004.

62. Takahashi Y. The 14-3-3 proteins: gene, gene expression, and function. Neurochem Res 28:1265-1273, 2003.

63. Vanhanen M, Soininen H. Glucose intolerance, cognitive impairment and Alzheimer's disease. Curr Opin Neurol 11:673-677, 1998.

64. Scheltens P, Korf ES. Contribution of neuroimaging in the diagnosis of Alzheimer's disease and other dementias. Curr Opin Neurol 13:391-396, 2000.

65. Messier C, Gagnon M. Glucose regulation and brain aging. J Nutr Health Aging 4:208-213, 2000.

66. Iwangoff P, Armbruster R, Enz A, Meier-Ruge W. Glycolytic enzymes from human autoptic brain cortex: normal aged and demented cases. Mech Ageing Dev 14:203-209, 1980.

67. Ogawa M, Fukuyama H, Ouchi Y, Yamauchi H, Kimura J. Altered energy metabolism in Alzheimer's disease. J Neurol Sci 139:78-82, 1996.

68. Casamenti F, Prosperi C, Scali C, Giovannelli L, Colivicchi MA, Faussone-Pellegrini MS, et al. Interleukin- $1 \beta$ activates forebrain glial cells and increases nitric oxide production and cortical glutamate and GABA release in vivo: implications for Alzheimer's disease. Neuroscience 91:831-842, 1999.

69. Li JY, Henning Jensen P, Dahlstrom A. Differential localization of $\alpha-, \beta$ - and $\gamma$-synucleins in the rat CNS. Neuroscience 113: 463-478, 2002.

70. Frolich L. The cholinergic pathology in Alzheimer's disease: discrepancies between clinical experience and pathophysiological findings. J Neural Transm 109:1003-1013, 2002.

71. Giovannini MG, Scali C, Prosperi C, Bellucci A, Vannucchi MG, Rosi $\mathrm{S}$, et al. $\beta$-amyloid-induced inflammation and cholinergic hypofunction in the rat brain in vivo: involvement of the p38MAPK pathway. Neurobiol Dis 11:257-274, 2002.

72. Bozner P, Wilson GL, Druzhyna NM, Bryant-Thomas TK, LeDoux SP, et al. Deficiency of chaperonin 60 in Down's syndrome. J Alzheimers Dis 4:479-486, 2002.

73. Lin KM, Lin B, Lian IY, Mestril R, Scheffler IE, Dillmann WH. Combined and individual mitochondrial HSP60 and HSP10 expression in cardiac myocytes protects mitochondrial function and prevents apoptotic cell deaths induced by simulated ischemiareoxygenation. Circulation 103:1787-1792, 2001.

74. Boyd-Kimball DPH, Lynn BC, Cai J, Pierce WM Jr, Klein JB, et al. Proteomic identification of proteins specifically oxidized in Caenorhabditis elegans expressing human A $\beta(1-42)$ : implications for Alzheimer's disease. Neurobiol Aging DOI:10.1016/ j.neurobiolaging. 2005.07.001

75. Castegna A, Thongboonkerd V, Klein J, Lynn BC, Wang YL, Osaka H, et al. Proteomic analysis of brain proteins in the gracile axonal dystrophy (gad) mouse, a syndrome that emanates from dysfunctional ubiquitin carboxyl-terminal hydrolase L-1, reveals oxidation of key proteins. J Neurochem 88:1540-1546, 2004.

76. Elder GA, Friedrich VL Jr, Lazzarini RA. Schwann cells and oligodendrocytes read distinct signals in establishing myelin sheath thickness. J Neurosci Res 65:493-499, 2001.

77. Beckman JS. Oxidative damage and tyrosine nitration from peroxynitrite. Chem Res Toxicol 9:836-844, 1996.

78. Chou SM, Wang HS, Taniguchi A, Bucala R. Advanced glycation endproducts in neurofilament conglomeration of motoneurons in familial and sporadic amyotrophic lateral sclerosis. Mol Med 4:324-332, 1998.

79. Cookson MR, Shaw PJ. Oxidative stress and motor neurone disease. Brain Pathol 9:165-186, 1999.

80. Butterfield DA, Howard BJ, Yatin S, Allen KL, Carney JM. Free radical oxidation of brain proteins in accelerated senescence and its modulation by $N$-tert-butyl- $\alpha$-phenylnitrone. Proc Natl Acad Sci USA 94:674-678, 1997.

81. Butterfield DA, Castegna A. Proteomics for the identification of specifically oxidized proteins in brain: technology and application to the study of neurodegenerative disorders. Amino Acids 25: 419-425, 2003

82. Takeda T, Hosokawa M, Takeshita S, Irino M, Higuchi K, Matsushita T, et al. A new murine model of accelerated senescence. Mech Aging Dev 17:183-194, 1981.

83. Chen GH, Wang YJ, Wang XM, Zhou JN, Liu RY. Effect of aging on species-typical behaviors in senescence-accelerated mouse. Physiol Behav 85:536-545, 2005.

84. Flood JF, Morley JE. Learning and memory in the SAMP8 mouse. Neurosci Biobehav Rev 22:1-20, 1998.

85. Butterfield DA, Poon HF. The senescence-accelerated prone mouse (SAMP8): a model of age-related cognitive decline with relevance to alterations of the gene expression and protein abnormalities in Alzheimer's disease. Exp Gerontol 40:774-783, 2005.

86. Farr SA, Poon HF, Dogrukol-Ak D, Drake J, Banks WA, Eyerman E, et al. The antioxidants $\alpha$-lipoic acid and $N$-acetylcysteine reverse memory impairment and brain oxidative stress in aged SAMP8 mice. J Neurochem 84:1173-1183, 2003.

87. Poon HF, Castegna A, Farr SA, Thongboonkerd V, Lynn BC, Banks WA, et al. Quantitative proteomics analysis of specific protein expression and oxidative modification in aged senescence-accelerated-prone 8 mice brain. Neuroscience 126:915926, 2004.

88. Kawamata T, Akiguchi I, Maeda K, Tanaka C, Higuchi K, Hosokawa M, et al. Age-related changes in the brains of senescence-accelerated mice (SAM): association with glial and endothelial reactions. Microsc Res Tech 43:59-67, 1998.

89. Shimano Y. [Studies on aging through analysis of the glucose metabolism related to the ATP-production of the senescence accelerated mouse (SAM)]. Hokkaido Igaku Zasshi 73:557-569, 1998.

90. Packer L, Roy S, Sen CK. $\alpha$-lipoic acid: a metabolic antioxidant and potential redox modulator of transcription. Adv Pharmacol 38:79-101, 1997.

91. Packer L, Tritschler HJ, Wessel K. Neuroprotection by the metabolic antioxidant $\alpha$-lipoic acid. Free Radic Biol Med 22:359378, 1997.

92. Kagan VE, Shvedova A, Serbinova E, Khan S, Swanson C, Powell R, et al. Dihydrolipoic acid-a universal antioxidant both in the membrane and in the aqueous phase: reduction of peroxyl, ascorbyl and chromanoxyl radicals. Biochem Pharmacol 44:1637-1649, 1992

93. Ou P, Tritschler HJ, Wolff SP. Thioctic (lipoic) acid: a therapeutic metal-chelating antioxidant? Biochem Pharmacol 50:123-126, 1995.

94. Sen CK, Roy S, Han D, Packer L. Regulation of cellular thiols in human lymphocytes by $\alpha$-lipoic acid: a flow cytometric analysis. Free Radic Biol Med 22:1241-1257, 1997.

95. Melone MA, Jori FP, Peluso G. Huntington's disease: new frontiers for molecular and cell therapy. Curr Drug Targets 6:43-56, 2005.

96. Muchowski PJ, Wacker JL. Modulation of neurodegeneration by molecular chaperones. Nat Rev Neurosci 6:11-22, 2005.

97. Kumar VB, Vyas K, Franko M, Choudhary V, Buddhiraju C, Alvarez J, et al. Molecular cloning, expression, and regulation of hippocampal amyloid precursor protein of senescence accelerated mouse (SAMP8). Biochem Cell Biol 79:57-67, 2001.

98. Poon HF, Joshi G, Sultana R, Farr SA, Banks WA, Morley JE, et al. Antisense directed at the A $\beta$ region of APP decreases brain oxidative markers in aged senescence accelerated mice. Brain Res 1018:86-96, 2004.

99. Bulliard C, Zurbriggen R, Tornare J, Faty M, Dastoor Z, Dreyer JL. Purification of a dichlorophenol-indophenol oxidoreductase from rat and bovine synaptic membranes: tight complex association of a glyceraldehyde-3-phosphate dehydrogenase isoform, TOAD64, enolase- $\gamma$ and aldolase C. Biochem J 324:555-563, 1997.

100. de Hostos EL, Bradtke B, Lottspeich F, Guggenheim R, Gerisch $\mathrm{G}$. Coronin, an actin binding protein of Dictyostelium discoideum 
localized to cell surface projections, has sequence similarities to G protein $\beta$ subunits. EMBO J 10:4097-4104, 1991.

101. Sarafian TA, Verity MA, Vinters HV, Shih CC, Shi L, Ji XD, et al. Differential expression of peroxiredoxin subtypes in human brain cell types. J Neurosci Res 56:206-212, 1999.

102. Kim H, Lee TH, Park ES, Suh JM, Park SJ, Chung HK, et al. Role of peroxiredoxins in regulating intracellular hydrogen peroxide and hydrogen peroxide-induced apoptosis in thyroid cells. J Biol Chem 275:18266-18270, 2000.

103. Butterfield D, Castegna A, Pocernich C, Drake J, Scapagnini G, Calabrese V. Nutritional approaches to combat oxidative stress in Alzheimer's disease. J Nutr Biochem 13:444, 2002.

104. Kirby J, Halligan E, Baptista MJ, Allen S, Heath PR, Holden H, et al. Mutant SOD1 alters the motor neuronal transcriptome: implications for familial ALS. Brain 128:1686-1706, 2005.

105. Andersen PM. Genetic factors in the early diagnosis of ALS. Amyotroph Lateral Scler Other Motor Neuron Disord 1:S31-S42, 2000.

106. Gurney ME. Transgenic animal models of familial amyotrophic lateral sclerosis. J Neurol 244:S15-S20, 1997.

107. Poon HF, Hensley K, Thongboonkerd V, Merchant ML, Lynn BC, Pierce WM, et al. Redox proteomics analysis of oxidatively modified proteins in G93A-SOD1 transgenic mice: a model of familial amyotrophic lateral sclerosis. Free Radic Biol Med 39: 453-462, 2005.

108. Andrus PK, Fleck TJ, Gurney ME, Hall ED. Protein oxidative damage in a transgenic mouse model of familial amyotrophic lateral sclerosis. J Neurochem 71:2041-2048, 1998.

109. Curti D, Malaspina A, Facchetti G, Camana C, Mazzini L, Tosca $\mathrm{P}$, et al. Amyotrophic lateral sclerosis: oxidative energy metabolism and calcium homeostasis in peripheral blood lymphocytes. Neurology 47:1060-1064, 1996.

110. Bergmann F, Keller BU. Impact of mitochondrial inhibition on excitability and cytosolic $\mathrm{Ca}^{2+}$ levels in brainstem motoneurones from mouse. J Physiol (Lond) 555:45-59, 2004.

111. Vigouroux S, Briand M, Briand Y. Linkage between the proteasome pathway and neurodegenerative diseases and aging. Mol Neurobiol 30:201-221, 2004.

112. Ganea E. Chaperone-like activity of $\alpha$-crystalline and other small heat shock proteins. Curr Protein Pept Sci 2:205-225, 2001.

113. Perluigi M, Fai Poon H, Hensley K, Pierce WM, Klein JB, Calabrese V, et al. Proteomic analysis of 4-hydroxy-2-nonenalmodified proteins in G93A-SOD1 transgenic mice: a model of familial amyotrophic lateral sclerosis. Free Radic Biol Med 38: 960-968, 2005.

114. Kieran D, Kalmar B, Dick JR, Riddoch-Contreras J, Burnstock G, Greensmith L. Treatment with arimoclomol, a coinducer of heat shock proteins, delays disease progression in ALS mice. Nat Med 10:402-405, 2004.

115. Zhang J, Goodlett DR. Proteomic approach to studying Parkinson's disease. Mol Neurobiol 29:271-288, 2004.

116. Recchia A, Debetto P, Negro A, Guidolin D, Skaper SD, Giusti P. $\alpha$-synuclein and Parkinson's disease. FASEB J 18:617-626, 2004.

117. Cabin DE, Shimazu K, Murphy D, Cole NB, Gottschalk W, McIlwain KL, et al. Synaptic vesicle depletion correlates with attenuated synaptic responses to prolonged repetitive stimulation in mice lacking $\alpha$-synuclein. J Neurosci 22:8797-8807, 2002.

118. Kruger R, Kuhn W, Muller T, Woitalla D, Graeber M, Kosel S, et al. Ala30Pro mutation in the gene encoding $\alpha$-synuclein in Parkinson's disease. Nat Genet 18:106-108, 1998.

119. De Iuliis A, Grigoletto J, Recchia A, Giusti P, Arslan P. A proteomic approach in the study of an animal model of Parkinson's disease. Clin Chim Acta 357:202-209, 2005.
120. Aksenov MY, Tucker HM, Nair P, Aksenova MV, Butterfield DA, Estus S, et al. The expression of key oxidative stress-handling genes in different brain regions in Alzheimer's disease. $J$ Mol Neurosci 11:151-164, 1998.

121. Ardley HC, Scott GB, Rose SA, Tan NG, Robinson PA. UCH-L1 aggresome formation in response to proteasome impairment in dicates a role in inclusion formation in Parkinson's disease. J Neurochem 90:379-391, 2004.

122. Canet-Aviles RM, Wilson MA, Miller DW, Ahmad R, McLendon C, Bandyopadhyay S, et al. The Parkinson's disease protein DJ-1 is neuroprotective due to cysteine-sulfinic acid-driven mitochondrial localization. Proc Natl Acad Sci USA 101:9103-9108, 2004

123. Valente EM, Abou-Sleiman PM, Caputo V, Muqit MM, Harvey K, Gispert S, et al. Hereditary early-onset Parkinson's disease caused by mutations in PINK1. Science 304:1158-1160, 2004.

124. von Coelln R, Dawson VL, Dawson TM. Parkin-associated Parkinson's disease. Cell Tissue Res 318:175-184, 2004.

125. Junn E, Mouradian MM. Human $\alpha$-synuclein over-expression increases intracellular reactive oxygen species levels and susceptibility to dopamine. Neurosci Lett 320:146-150, 2002.

126. Poon HF, Frasier M, Shreve N, Calabrese V, Wolozin B, Butterfield DA. Mitochondrial associated metabolic proteins are selectively oxidized in A30P $\alpha$-synuclein transgenic mice: a model of familial Parkinson's disease. Neurobiol Dis 18:492-498, 2005.

127. Kremer B, Weber B, Hayden MR. New insights into the clinical features, pathogenesis and molecular genetics of Huntington's disease. Brain Pathol 2:321-335, 1992.

128. Leavitt BR, Wellington CL, Hayden MR. Recent insights into the molecular pathogenesis of Huntington's disease. Semin Neurol 19:385-395, 1999.

129. Burke JR, Enghild JJ, Martin ME, Jou YS, Myers RM, Roses AD, et al. Huntington and DRPLA proteins selectively interact with the enzyme GAPDH. Nat Med 2:347-350, 1996.

130. Saunders PA, Chen RW, Chuang DM. Nuclear translocation of glyceraldehyde-3-phosphate dehydrogenase isoforms during neuronal apoptosis. J Neurochem 72:925-932, 1999.

131. Sawa A, Khan AA, Hester LD, Snyder SH. Glyceraldehyde-3phosphate dehydrogenase: nuclear translocation participates in neuronal and nonneuronal cell death. Proc Natl Acad Sci USA 94:11669-11674, 1997.

132. Calabresi P, Gubellini P, Picconi B, Centonze D, Pisani A, Bonsi $\mathrm{P}$, et al. Inhibition of mitochondrial complex II induces a longterm potentiation of NMDA-mediated synaptic excitation in the striatum requiring endogenous dopamine. J Neurosci 21:5110$5120,2001$.

133. LaFontaine MA, Geddes JW, Butterfield DA. 3-Nitropropionic acid-induced changes in bilayer fluidity in synaptosomal membranes: implications for Huntington's disease. Neurochem Res 27:507-511, 2002.

134. Fontaine MA, Geddes JW, Banks A, Butterfield DA. Effect of exogenous and endogenous antioxidants on 3-nitropionic acidinduced in vivo oxidative stress and striatal lesions: insights into Huntington's disease. J Neurochem 75:1709-1715, 2000.

135. Perluigi M, Poon HF, Maragos W, Pierce WM, Klein JB, Calabrese V, et al. Proteomic analysis of protein expression and oxidative modification in $\mathrm{r} 6 / 2$ transgenic mice: a model of Huntington's disease. Mol Cell Proteomics 4:1849-1861, 2005.

136. Sultana RPH, Cai J, Pierce WM, Merchant M, Klein JB, et al. Identification of nitrated proteins in Alzheimer's disease brain using a redox proteomics approach. Neurobiol Dis DOI:10.1016/ j.neurobiolaging. 2005.05.005

137. Vis JC, de Boer-van Huizen RT, Verbeek MM, de Waal RM, ten Donkelaar HJ, Kremer B. Creatine protects against 3-nitropropionic acid-induced cell death in murine corticostriatal slice cultures. Brain Res 1024:16-24, 2004. 